\title{
Evaluasi Kebijakan Internasionalisasi Universitas Brawijaya Dalam Rangka Menuju World Class University
}

\author{
Muamar Khadafi ${ }^{a} *$, Bambang Santoso Haryono ${ }^{b}$, Alfi Haris Wanto ${ }^{c}$ \\ ${ }^{a b c}$ Universitas Brawijaya, Malang, Jawa Timur, Indonesia
}

\section{INFORMASI ARTIKEL}

\section{Article history:}

Dikirim tanggal: 20 April 2018

Revisi pertama tanggal: 15 Mei 2018

Diterima tanggal: 28 Juni 2018

Tersedia online tanggal: 27 Agustus 2018

Keywords: internationalization, evaluation policy, world class university

\section{ABSTRACT}

University role in supporting internationalization is considered necessary to be implemented because the issue of internationalization is one of the impact of globalization, not only in the field of information technology but also in education. Brawijaya University has committed to become a world-class university through its policies to support the goal of Universitas Brawijaya become World Class University. To reach that stage, the internationalization policy adopted by UB must be truly targeted. The results of the research indicate that the assessment of the implementation of UB's internationalization policy in terms of inputs, processes and outputs indicates the inefficiency of the implementation of the policy because it has not balanced the input, process, and the results obtained, while several obstacles found in the process of Internationalisation.

\section{INTISARI}

Peran universitas dalam menunjang internasionalisasi ini dianggap perlu untuk dilaksanakan karena isu internasionalisasi merupakan salah satu dampak globalisasi dunia, tidak hanya dalam bidang teknologi informasi tetapi juga dalam bidang pendidikan. Universitas Brawijaya telah berkomitmen untuk menjadi universitas berkelas dunia melalui kebijakan-kebijakannya untuk menunjang tujuan Universitas Brawijaya menjadi World Class University. Untuk menuju tahap tersebut, kebijakan internasionalisasi yang diambil oleh UB harus benarbenar setap sasaran. Penelitian ini bertujuan untuk mendeskripsikan evaluasi pelaksanaan kebijakan internasionalisasi dan kendala pelaksanaannya di Universitas Brawijaya. Hasil dari penelitian ini menunjukkan bahwa penilaian terhadap pelaksanaan kebijakan internasionalisasi UB dari segi input, proses, dan output mengindikasikan masih belum efisiennya pelaksanaan kebijakan tersebut karena belum seimbangnya input, proses, dan hasil yang diperoleh. Sementara beberapa kendala juga ditemukan dalam proses internasionalisasi tersebut.

2018 FIA UB. All rights reserved.

\section{Pendahuluan}

Globalisasi telah menimbulkan mobilitas sumber daya manusia antar negara. Oleh sebab itu investasi sangat dibutuhkan untuk dihasilkannya tenaga kerja yang mampu beradaptasi pada situasi lintas budaya dengan menguasai ketrampilan dan pengetahuan baru, multi-bahasa, komunikasi, negosiasi, pemahaman 
budaya dan aturan antar negara. Kualitas lulusan perguruan tinggi akan semakin menjadi ukuran daya saing bangsa dalam percaturan global. Dengan kata lain, perguruan tinggi semakin dituntut menjadi ujung tombak pembentukan masyarakat berbasis ilmu pengetahuan serta menghasilkan lulusan sebagai anggota masyarakat global. Internasionalisasi perguruan tinggi menjadi suatu hal yang tidak terelakan.

Salah satu komitmen pemerintah dalam menghadapi globalisasi pendidikan tinggi tertuang dalam Undang Undang Republik Indonesia No.12 tahun 2012 tentang Pendidikan Tinggi pada bagian keempat belas. Dalam penjelasan umum UU No.12 Tahun 2012 tentang Pendidikan Tinggi tersebut juga disebutkan "Perguruan Tinggi sebagai lembaga yang menyelenggarakan Pendidikan Tinggi Penelitian dan Pengabdian kepada Masyarakat, harus memiliki otonomi dalam mengelola sendiri lembaganya. Hal itu diperlukan agar dalam pengembangan Ilmu Pengetahuan dan Teknologi di Perguruan Tinggi berlaku kebebasan akademik dan mimbar akademik, serta otonomi keilmuan.

\section{The Growth of International Student Mobility, 1990-2014}

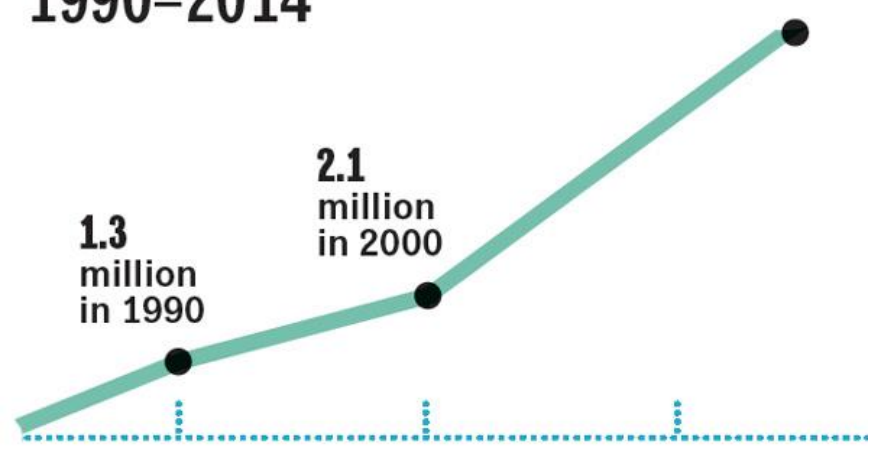

Gambar 1 Pertumbuhan Mobilitas Mahasiswa Asing Sumber: ICEF, 2015

Berdasarkan gambar 1 dapat diketahui bahwa pertumbuhan mobilitas mahasiswa asing mengalami pertumbuhan yang sangat pesat dalam 25 tahun terakhir telah direkam oleh ICEF Monitor sebagai Market Intelligence Resource for the International Education and Student Travel Agency (www.monitor.icef.com). Adapun jumlah pertumbuhan mobilitas mahasiswa asing berkembang dari angka 1.3 juta mahasiswa pada Tahun 1990 menjadi 2.1 juta mahasiswa pada Tahun 2000 dan menjadi 5 juta mahasiswa pada Tahun 2014. Berdasarkan data tersebut dapat diketahui bahwa pengembangan cakupan berskala internasional menjadi tuntutan wajib bagi perguruan tinggi sebagai lembaga penyelenggara pendidikan guna mendukung pengembangan pendidikan dan ilmu pengetahuan yang berkualitas dan mampu bersaing di ranah global.

Pada era globalisasi perguruan tinggi semakin dituntut untuk menciptakan anggota masyarakat global. Sejalan dengan itu, perjanjian-perjanjian yang diikuti dengan perubahan kelembagaan internasional semakin menguat. Merespon hal tersebut maka perguruan perguruan tinggi di benua Eropa, Amerika, Australia sebagian Asia dan Jepang telah memiliki unit internasional sebagai unit yang menjembatani mereka dengan lingkungan international. QS World University Ranking menempatkan universitas-universitas di Indonesia pada peringkat 700 besar, jauh di bawah peringkat negara-negara tetangga seperti Singapura, Malaysia, atau Australia. Peringkat 100 besar banyak dihuni oleh Universitas dari negara maju dari Amerika Serikat dan Eropa. Pemeringkatan lain seperti Webometrics menempatkan Universitas di Indonesia di rata-rata 1500 besar, bahkan Times Higher Education World Ranking tidak menempatkan satupun perguruan tinggi di Indonesia pada daftar rankingnya.

Universitas Brawijaya adalah salah satu universitas terbesar di Indonesia, dengan jumlah mahasiswa lebih dari 60.000 orang dan 157 program studi. Universitas Brawijaya melalui Rencana Strategis 2011-2015 (UB, 2011) telah menuangkan semangat untuk internasionalisasi dengan bertujuan untuk menjadi World Class Entrepreneurial University, serta visinya yaitu menjadi "Universitas Unggul Berstandar Internasional dan Mampu Berperan Aktif Dalam Pembangunan Bangsa Melalui Proses Pendidikan, Penelitian, dan Pengabdian Kepada Masyarakat". Agar visi tersebut bisa sukses terwujud, Universitas Brawijaya perlu memahami dinamika proses internasionalisasi dan hubungannya dengan faktorfaktor organisasi, terlebih lagi internasionalisasi menjadi elemen pusat dari perencanaan strategis Perguruan Tinggi. Oleh sebab itu proses internasionaliasi Perguruan Tinggi memerlukan evaluasi kebijakan agar proses internasionalisasi tersebut bisa berkesinambungan sampai sebuah Perguruan Tinggi bisa dikatakan mencapai tahap internasional atau World Class University.

Adapun tujuan dari penelitian ini adalah untuk (a) mendeskripsikan evaluasi pelaksanaan kebijakan internasionalisasi di Universitas Brawijaya; dan (b) mendeskripsikan kendala dalam pelaksanaan kebijakan internasionalisasi di Universitas Brawijaya dalam rangka menuju World Class University. Penelitian ini diharapkan sebagai proses monitoring dan evaluasi tentang kebijakan internasionalisasi UB, serta dapat 
memberikan masukan-masukan bagaimana proses internasionalisasi yang efektif menuju World Class Entrepreneurial University.

\section{Teori}

\subsection{Konsep Kebijakan Publik}

Thomas R. Dye (1992:33) menyebutkan kebijakan publik ialah apa yang tidak dilakukan maupun yang dilakukan oleh pemerintah. Selain itu, kajiannya hanya terfokus pada negara sebagai pokok kajian. Definisi tersebut dapat dikategorikan sebagai sebuah keputusan atau decision making walaupun itu termasuk sebuah keputusan untuk membiarkan sesuatu yang terjadi agar bisa teratasinya suatu persoalan publik.

Kebijakan publik menurut Edward \& Sharkansky (dalam Wahab, 2008:51-52) adalah: "what governments say and do, or do not do. It is the goals or purposes of governments programs". Pengertiannya adalah penekanan pada apa yang dilakukan dan dinyatakan atau tidak dilakukan oleh pemerintah termasuk kebijakan publik. Berdasarkan pada definisi yang tersebut, kebijakan publik muncul sebagai tujuan maupun sasaran dari program pemerintah. Lebih jauh, Edward \& Sharkansky mengemukakan bahwa kebijakan itu dapat diterapkan dan ditunjukan secara jelas dan tercatat di peraturan perundang-undangan dalam bentuk pidatopidato pejabat, program yang disosialisasikan maupun tindakan yang dilakukan pemerintah.

\subsection{Konsep Evaluasi Kebijakan Publik}

Evaluasi merupakan tahap akhir dalam proses kebijakan. Winarno (2012:229) mengemukakan evaluasi kebijakan dapat dikatakan sebagai kegiatan yang menyangkut estimasi atau penilaian kebijakan yang mencakup substansi, implementasi dan dampak merupakan langkah terakhir dalam suatu kebijakan. Evaluasi kebijakan dipandang sebagai suatu kegiatan yang fungsional. Evaluasi kebijakan dapat meliputi tahap perumusan masalah-masalah kebijakan, programprogram yang diusulkan untuk menyelesaikan masalah kebijakan, implementasi, maupun tahap dampak kebijakan.

Nawawi (2009:155) menyatakan bahwa evaluasi adalah suatu aktivitas yang dirancang untuk mempertimbangkan manfaat program dan proses pemerintahan. Pendapat tersebut identik dengan penilaian terhadap output dan proses kebijakan. Berdasarkan pendapat tersebut, untuk memperoleh kejelasan mengenai faktor-faktor yang menyebabkan berhasil atau gagalnya suatu kebijakan yang sedang dilaksanakan, seorang evaluator harus menganalisis kerangka pemikiran teoritik dan konseptual yang menjadi dasar penyusunan program pemerintah tersebut.
Dengan demikian bisa dimungkinkan untuk diketahui letak kelemahan-kelemahan program disebabkan oleh terjadinya kesalahan atau gagalnya implementasi ataukah kegagalan tersebut terletak pada perumusan konsepsi awal dan landasan teoritikal dari kebijakan tersebut.

Dari beberapa pendapat di atas, maka dapat ditarik kesimpulan bahwa evaluasi kebijakan menjadi salah satu tahapan untuk proses memonitoring dan menilai kinerja dan hasil kebijakan. Dalam penelitian ini, pemahaman terkait evaluasi kebijakan publik digunakan sebagai landasan evaluasi program internasionalisasi yang dilakukan oleh Universitas Brawijaya dalam upayanya untuk mencapai tujuan menjadi World Class University. Dalam penelitian ini digunakan metode analisis evaluasi formatif. Pendekatan evaluasi formatif adalah bagian dari pendekatan evaluasi formal, yaitu pendekatan yang menggunakan metode deskriptif untuk mendapatkan informasi yang valid, cepat dan dapat dipercaya mengenai hasil-hasil kebijakan. Hasil evaluasi tersebut diberikan berdasarkan tujuan program kebijakan yang telah disebutkan secara formal oleh pembuat kebijakan dan pelaksana program (Dunn, 2000:499). Evaluasi formal menggunakan undangundang, dokumen-dokumen program, dan wawancara dengan pembuat kebijakan dan administrator untuk mendapatkan identifikasi, definisi dan spesifikasi baik tujuan maupun target. Sesuai tahapannya, evaluasi yang digunakan adalah evaluasi input, evaluasi proses dan evaluasi output.

\subsection{Internasionalisasi Pendidikan Tinggi}

Definisi dari internasionalisasi sangat kompleks dan luas, tergantung pada interpretasi institusi yang mengadopsinya, dimana definisi tersebut mempengaruhi pendekatan mereka untuk mencapai internasionalisasi. Internasionalisasi mengacu pada "Beberapa kegiatan, program dan layanan di lingkungan studi, pertukaran pendidikan dan kerjasama internasional" (Harari, 1977:13).

Internasionalisasi pendidikan tinggi terutama mencakup mobilitas fakultas dan mahasiswa, alat bantu pendidikan dan kerjasama internasional, serta internasionalisasi kurikulum. Dengan kata lain, internasionalisasi pendidikan tinggi meliputi pertukaran fakultas dan mahasiswa, pengajaran bersama dan program penelitian serta internasionalisasi kurikulum (Yunlai \& Zhehua, 2008:3).

Untuk memahami konsep internasionalisasi pada level institusional, perlu diidentifikasi apa indikator yang digunakan untuk mengukur bagaimana sebuah institusi telah secara komprehensif melakukan proses internasionalisasi. Ellingboe (1998:199) menyebutkan ada enam komponen yang mengindikasikan 
internasionalisasi sebuah institusi, antara lain: "college leadership, faculty participation, internationalized curriculum, study abroad, integration of international students, and international extra cullicular activities". Kepemimpinan dalam hal ini tidak berkaitan dengan gaya atau efektifitas kepemimpinan, namun lebih kepada hubungan antara pemimpin dan administrator senior untuk menentukan kebijakan dan rencana strategi internasionalisasi.

\section{Metode Penelitian}

Penelitian ini menerapkan metode penelitian kualitatif. Penggunaan metode penelitian kualitatif dalam studi evaluasi kebijakan internasionalisasi UB yang bertujuan untuk mendapatkan data yang lebih terbuka dan analisis yang lebih mendalam.

Penelitian ini menggunakan data primer yang bersumber dari informan dan laporan hasil FGD serta data sekunder yang berasal dari dokumen-dokumen, arsip-arsip, catatan-catatan dan laporan resmi. Adapun sumber data dalam penelitian ini berasal dari Laporan $F G D$, Wawancara, Observasi, Dokumen. Pengumpulan data dilakukan dengan metode FGD, Wawancara, Observasi, dan Dokumentasi.

Pelaksanaan FGD sendiri dilakukan beriringan dengan kegiatan yang ditentukan Universitas Brawijaya, yakni dalam (a) Diskusi Penerimaan Mahasiswa Asing; (b) Diskusi Indbound World Class Professor; (c) Workshop Kerjasama Internasional; (d) Rapat Kerja Internasional Office UB; dan (e) Diskusi Finalisasi Draft Internasionalisasi. Kemudian dilanjutkan dengan pengumpulan data melalui kegiatan wawancara kepada informan kunci. Adapun informan kunci dalam penelitian ini telah ditentukan sebelumya, yakni Kepala bagian International Office UB dan KJF kerjasama internasional/ manajemen representatif IOUB. Selanjutnya, penelitian dilakukan dengan studi dokumentasi dan observasi lapangan guna memberikan informasi tambahan terkait data yang dikumpulkan.

Setelah data FGD dan wawancara terkumpul, maka dilakukan penyusunan hasil analisis. Selanjutnya dilakukan pengumpulan data tambahan sebagai pendukung informasi yang telah terkumpul yakni menggunakan teknik observasi studi literatur, dan wawancara kepada informan tambahan. Adapun kegiatan ini dilakukan sebagai bentuk validasi data untuk menjaga keabsahan data yang dikumpulkan serta memberikan deskripsi lebih detail terkait informasi terkait fokus penelitian. Obsevasi dan studi literatur yang dilakukan dalam penelitian ini berupa evaluasi input kebijakan, evaluasi pelaksanaan proses kebijakan, dan evaluasi output kebijakan internasionalisasi UB. Kemudian wawancara tambahan dilakukan untuk mengklarifikasi hasil dari temuan yang diperoleh kepada informan tambahan yang bersangkutan langsung dengan bagian yang diteliti. Adapun informan tambahan dalam penelitian ini ditentukan sebelumnya, yakni (a) Ka. Subbag. Umum dan Keuangan International Office UB; (b) Staf International Office (bagian sarana dan prasarana); dan (c) bagian kurikulum dari salah satu fakultas yang memiliki kelas internasional di UB (dalam penelitian ini dipilih informan dari FEB UB).

Adapun yang menjadi fokus dalam penelitian ini adalah:

a) Evaluasi pelaksanaan kebijakan internasionalisasi UB, meliputi: (1) Input dalam hal ini adalah sumber daya manusia, pendanaan, sarana dan prasarana; (2) Konsistensi proses dalam hal ini adalah proses pelaksanaan kebijakan internasionalisasi; dan (3) Hasil yang telah dicapai selama pelaksanaan kebijakan; dan

b) Kendala yang terjadi pada pelaksanaan kebijakan Internasionalisasi UB meliputi Kendala internal dan Kendala eksternal.

Peneliti dalam penelitian ini mempunyai parameter atau standar penilaian yang digunakan sebagai instrumen evaluasi, namun tetap mengacu pada kaidah penelitian kualitatif yang digunakan sebagai instrumen evaluasi. Ukuran yang ditetapkan untuk kesesuaian kesesuaian antara policy guideline dengan informasi informan adalah:

Tabel 1 Penilaian Kesesuaian antara Policy Guideline dengan Informasi Informan

\begin{tabular}{|c|c|}
\hline Nilai & Kriteria \\
\hline Baik & $\begin{array}{l}\text { Pencapaian program/ kegiatan terlaksana dengan baik berdasarkan policy guideline dan } \\
\text { keterangan informan. Memiliki kesesuaian yang baik antara perencanaan, proses, dan hasil } \\
\text { secara kualitas dan kuantitas }\end{array}$ \\
\hline Cukup & $\begin{array}{l}\text { a) Pencapaian program/ kegiatan terlaksana dengan cukup baik berdasarkan policy } \\
\text { guideline dan keterangan informan. Memiliki kesesuaian yang baik antara perencanaan, } \\
\text { proses, dan hasil secara kualitas tapi belum disertai dengan kuantitas yang baik } \\
\text { b) Pencapaian program/ kegiatan terlaksana dengan cukup baik berdasarkan policy } \\
\text { guideline dan keterangan informan. Memiliki kesesuaian yang baik antara perencanaan, } \\
\text { proses, dan hasil secara kuantitas tapi belum disertai dengan kualitas yang baik }\end{array}$ \\
\hline Kurang & a) Pencapaian program/ kegiatan terlaksana dengan kurang baik berdasarkan policy \\
\hline
\end{tabular}




\begin{tabular}{|c|c|}
\hline Nilai & Kriteria \\
\hline & $\begin{array}{l}\text { guideline dan keterangan informan. Memiliki kualitas dan kuantitas yang baik pada } \\
\text { masing-masing tahap baik perencanaan, proses, dan hasil, tapi tidak memiliki kesesuaian } \\
\text { dalam proses pelaksanaannya (bagus secara teoritis tapi tidak terkoordinasi dengan baik } \\
\text { dan berjalan sendiri-sendiri) } \\
\text { b) Pencapaian program/ kegiatan terlaksana dengan kurang baik berdasarkan policy } \\
\text { guideline dan keterangan informan. Memiliki kualitas dan kuantitas yang buruk pada } \\
\text { masing-masing tahap baik perencanaan, proses, dan hasil, tapi memiliki kesesuaian } \\
\text { dalam proses pelaksanaannya (bagus secara koordinasi tapi tidak sesuai dengan teori) }\end{array}$ \\
\hline Sangat Kurang & $\begin{array}{l}\text { Pencapaian program/ kegiatan terlaksana dengan buruk berdasarkan policy guideline dan } \\
\text { keterangan informan. Pada masing-masing tahan baik perencanaan, proses, dan hasil tidak } \\
\text { memiliki kualitas dan kuantitas }\end{array}$ \\
\hline
\end{tabular}

Sumber: Patton \& Sawicki (1993:185)

Parameter tersebut disusun berdasarkan pendekatan dasar yang digunakan dalam evaluasi kebijakan dalam penelitian ini. Adapun pendekatan dasar yang digunakan dalam evaluasi kebijakan adalah Actual versus planed performance comparisons. Metode ini mengkaji suatu objek penelitian dengan membandingkan kondisi yang ada (actual) dengan ketetapan-ketetapan perencanaan yang ada (planned)(Patton \& Sawicki, 1993:185).

Lebih lanjut, untuk bisa mengetahui apakah sebuah program kebijakan telah terlaksana dengan baik, maka dibutuhkan ukuran yang terkait dengan penilaian terhadap informasi informan. Berpedoman pada Four Categories of Information Produced by Evaluation yang dijelaskan oleh Thompson \& McClintock (2000:11), maka standar yang dibuat adalah sebagai berikut:

Tabel 2 Penilaian Terhadap Informasi Informan

\begin{tabular}{|l|l|}
\hline \multicolumn{1}{|c|}{$\begin{array}{c}\text { Kriteria Informasi } \\
\text { Informan }\end{array}$} & \multicolumn{1}{c|}{ Penilaian } \\
\hline $\begin{array}{l}\text { Mengetahui dan } \\
\text { memahami }\end{array}$ & $\begin{array}{l}\text { Program berjalan } \\
\text { dengan baik }\end{array}$ \\
\hline $\begin{array}{l}\text { Mengetahui tetapi tidak } \\
\text { memahami }\end{array}$ & $\begin{array}{l}\text { Program berjalan } \\
\text { dengan baik dan perlu } \\
\text { peningkatan }\end{array}$ \\
\hline $\begin{array}{l}\text { Tidak mengetahui tetapi } \\
\text { memahami }\end{array}$ & $\begin{array}{l}\text { Program perlu } \\
\text { peningkatan dan } \\
\text { perbaikan }\end{array}$ \\
\hline $\begin{array}{l}\text { Tidak mengetahui dan } \\
\text { tidak memahami }\end{array}$ & $\begin{array}{l}\text { Program perlu } \\
\text { perbaikan }\end{array}$ \\
\hline
\end{tabular}

Sumber: Thompson \& McClintock (2000:11)

Paramater ini digunakan sebagai dasar penilaian pemahaman konsep internasionalisasi perguruan tinggi yang dilakukan Universitas Brawijaya saat ini. Pemilihan indikator-indikator ini sebagai parameter penilaian adalah karena teori ini dianggap mampu dan sesuai untuk melihat sejauh mana pemahaman informan dalam merealisasikan konsep internsionalisasi dalam bentuk pengembangan dan pelaksanaan kebijakan publik terkait program internasionlisasi UB. Asumsinya dengan pemahaman yang baik dan pelaksanaan yang sesuai maka akan dihasilkan sistem pengembangan program internasionalisasi yang baik pula, baik pada tahap perencanaan (input), pelaksanaan (proses), dan pencapaian hasil dan prestasi (output).

Analisa data pada penelitian ini menggunakan pendekatan linear dan hierarkhis yang dimulai dari bawah ke atas. Teknik analisis data menggunakan pendekatan linear dan hierarkhis dipilih karena dianggap sesuai dengan skema induktif pada penelitian ini dimana analisis dan penarikan kesimpulan penelitian berkembang berdasarkan temuan yang diperoleh di lapangan. Adapun detail analisisnya ditunjukkan pada gambar 2.

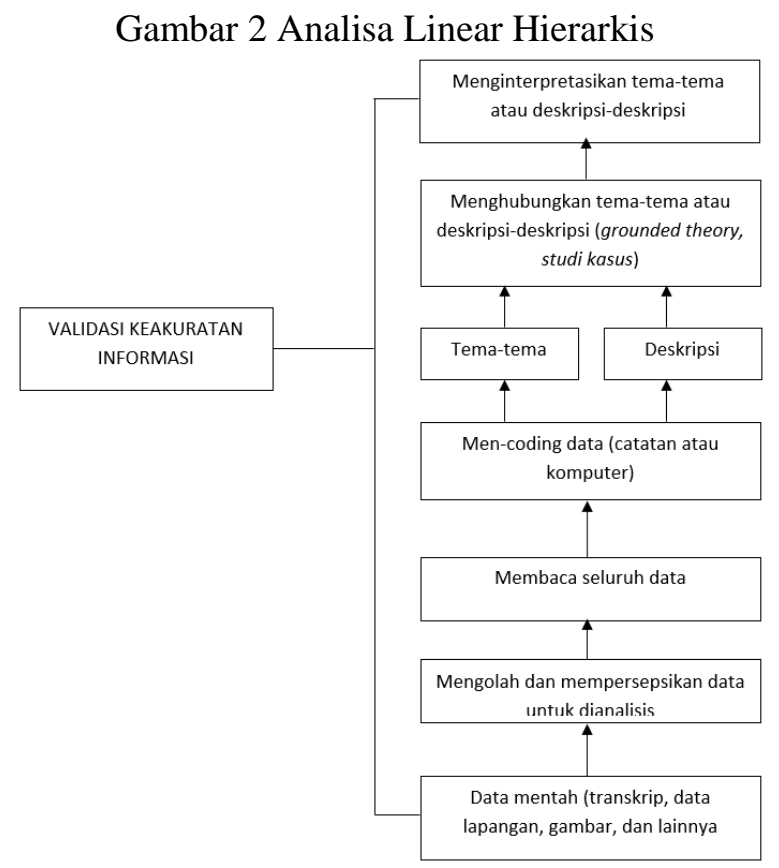

Sumber: Creswell (2012:277)

\section{Hasil Penelitian dan Pembahasan}

\subsection{Analisis Evaluasi Kebijakan Internasionalisasi Universitas Brawijaya}

Program internasionalisasi merupakan realiasasi 
keinginan civitas akademik UB untuk secara eksplisit menuju internasionalisasi lembaga guna menyongsong persaingan global. Terkait bentuk kebijakan internasionalisasi UB sendiri hingga saat ini belum dituangkan dalam suatu peraturan khusus. Dengan demikian, pelaksanaan program internasionalisasi UB saat ini masih mengacu pada beberapa kebijakan lain seperti Peraturan Pemerintah No.66 Tahun 2010 (tentang Pengelolaan dan Penyelenggaraan Pendidikan), SK Rektor no 287 tahun 2015 (tentang Pengangkatan Personalia Kantor Urusan Internasional UB), SK Rektor No. 115 Tahun 2015 (tentang Struktur Organisasi Kantor Urusan Internasional Universitas Brawijaya).

Meskipun belum terdapat kebijakan khusus yang menyatakan secara jelas terkait pengembangan program internasionalisasi UB, kisi-kisi dan arah pengembangan UB sebagai universitas bertaraf internasional dijelaskan secara rinci dalam Rencana Strategis UB 2015-2019. Dalam restra ini, dijelaskan bahwa Sesuai amanat Undang-Undang Pendidikan Tinggi (UUPT) No. 12 Tahun 2012, Universitas Brawijaya mempunyai kewajiban melaksanakan pendidikan, penelitian dan pengabdian kepada masyarakat yang memiliki daya saing baik ditingkat nasional maupun di tingkat internasional (UB, 2015). Dalam Restra UB 2015-2019 tersebut ditunjukkan bahwa visi dari universitas brawijaya saat ini adalah "Menjadi universitas unggul yang berstandar internasional dan mampu berperan aktif dalam pembangunan bangsa melalui proses pendidikan, penelitian, dan pengabdian kepada masyarakat". Hal ini menunjukkan bahwa visi pengembangan Universitas Brawijaya saat ini diarahkan pada program internasionalisasi. Secara khusus, analisis kebijakan internasionalisasi UB dilakukan dengan melihat efisiensi pelaksanaan kebijakan berdasarkan tahap evaluasi. Sesuai tahapan evaluasi yang dipakai, evaluasi yang dipergunakan pada penelitian ini adalah adalah evaluasi input, evaluasi proses dan evaluasi output. Berikut disajikan rincian pembahasan hasil temuan penelitian berdasarkan masing-masing pin evaluasi input, evaluasi proses dan evaluasi output.

Pertama, pada tahap evaluasi input peneliti menekankan input pembiayaan, sarana \& prasarana, dan SDM. Berikut disajikan tabel analisis evaluasi input pada Tabel 3:

Tabel 3 Hasil Analisis Evaluasi Input

\begin{tabular}{|c|l|c|}
\hline No & \multicolumn{1}{|c|}{ Parameter } & Kriteria \\
\hline 1 & Pembiayaan & Baik \\
\hline 2 & Sarana \& Prasarana & Kurang Baik \\
\hline 3 & SDM & Kurang Baik \\
\hline
\end{tabular}

Sumber: Hasil analisis, 2018

Berdasarkan hasil analisis data, penilaian input pembiayaan dapat dikatakan Baik. Hal ini dapat dilihat dari tidak adanya alokasi keperluan yang tidak dianggarkan dan nilai nominal anggaran yang tidak melenceng jauh dari alokasi yang dicanangkan. Selain itu, melihat persentase capaian kegiatan dan alokasi dana yang dianggarkan maka penggunaan input keuangan dapat dikatakan baik.

Kemudian berdasarkan hasil penilaian input sarana dan prasarana dapat dikatakan Kurang Baik. Dalam hal input sarana dan prasarana, penyediaan berbagai fasilitas seperti gedung, lab, dan fasilitas terkait program internasionalisasi UB menunjukkan bahwa upaya pemenuhan input ini sudah terlaksana. Hanya saja melihat masukan dari hasil evaluasi QS Stars menunjukkan masih adanya perbaikan input saranaprasarana dalam program internasionlisasi UB. Berdasarkan hasil evaluasi QS Stars, pada bidang facility, dinyatakan bahwa ketersediaan akomodasi dan fasilitas gedung mahasiswa yang belum sebanding dengan jumlah mahasiswa baru yang diterima di UB. Hal ini menjadi salah satu fokus utama bagi pihak UB untuk memenuhi standart program internasionalisasi UB (Tim Internasionalisasi UB, 2015).

Dalam FGD yang dilakukan juga ditemukan bahwa terdapat beberapa pemanfaatan fasilitas yang masih belum optimal. Hal ini bisa menjadi faktor penunjang internasionalisasi yang belum sepenuhnya terstruktur dengan baik di Universitas Brawijaya. Berbagai temuan dalam penelitian ini menunjukkan bahwa berbagai fasilitas yang disediakan demi keberlangsungan program kelas internasional di UB masih memiliki beberapa kelemahan yang bersifat menghambat. Salah satu contoh keberadaan fasilitas yang belum berperan optimal sesuai fungsinya adalah ketersediaan informasi kemahasiswaan melalui sistem informasi online yang tersedia. Selama ini sistem informasi kemahasiswaan online sudah tersedia, yakni pada http://io.ub.ac.id/ dan https://selma.ub.ac.id/en/seleksi-masuk-internasional (untuk urusan penerimaan mahasiswa baru kelas internasional).

Selanjutnya pada berdasarkan hasil penilaian input SDM juga dapat dikatakan Kurang Baik. Pada input sumber daya manusia, penyediaan SDM juga masih belum bisa dikatakan optimal. Berdasarkan hasil evaluasi QS Stars menunjukkan masih adanya perbaikan input kepegawaian dalam program internasionlisasi UB. Berdasarkan hasil evaluasi QS Stars, pada bidang employability, jumlah perusahaan internasional yang merekrut alumni UB masih di bawah angka 40 . Kemudian dalam hal tenaga pengajar, rasio mahasiswa dibanding dosen pengajar juga belum mencapai rasio 10:1, sehingga berpengaruh pula pada kategori teaching yang belum optimal. Hal ini menunjukkan bahwa input sumber daya manusia yang disediakan UB masih belum bisa dikatakan memenuhi standart internasional (Tim 
Internasionalisasi UB, 2015).

Berdasarkan temuan di lapangan dapat pula dilihat bahwa pendidikan khusus pegawai administrasi di International Office UB dapat dikatakan kurang relevan dengan kualifikasi yang dibutuhkan. Meskipun demikian, kondisi ini masih ditolerir dengan alasan sebagai berikut:

a) Kurangnya sumber daya manusia pengelola, sehingga memaksimalkan kerja sumber daya manusia yang ada;

b) Belum adanya peraturan atau SK Rektor yang mengatur tentang rincian jabatan dan kepegawaian untuk International Office UB; dan

c) Administrator di International Office telah mengikuti bimbingan teknis administrator sesuai fungsi dan jabatannya.

Dengan demikian, kondisi sumber daya manusia yang terbatas serta tingginya beban kinerja yang harus ditanggung dianggap masih dapat diatasi dengan memaksimalkan tugas dan fungsi pegawai dapat tetap yang dianggap mampu melaksanakan tugas dengan cukup baik.

Kedua, evaluasi dari segi proses, sudah banyak kebijakan internasionalisasi UB yang sudah dijalankan dan terus dikembangkan guna menaikkan kualitas UB sebagai international univesity. Dari beberapa kebijakan tersebut peneliti menitik beratkan pada pelaksanaan pengembangan kurikulum, kualitas sumber daya manusia, dan upaya perbaikan reputasi UB sebagai international university. Ketiga faktor ini dirasa menjadi salah satu faktor kompleks yang perlu dikembangkan guna membangun world class university yang menjadi tujuan pengembangan program internasionalisasi UB saat ini. Berikut disajikan tabel analisis evaluasi proses pada Tabel 4:

Tabel 4 Hasil Analisis Evaluasi Proses

\begin{tabular}{|c|l|l|}
\hline No & \multicolumn{1}{|c|}{ Parameter } & Kriteria \\
\hline 1 & $\begin{array}{l}\text { Pelaksanaan pengembangan } \\
\text { kurikulum }\end{array}$ & Cukup \\
\hline 2 & $\begin{array}{l}\text { Pengembangan kualitas } \\
\text { sumber daya manusia } \\
\text { pengajar }\end{array}$ & Kurang Baik \\
\hline 3 & Upaya perbaikan reputasi & Sangat kurang \\
\hline
\end{tabular}

Sumber: Hasil analisis, 2018

Berdasarkan hasil analisis data, penilaian proses pelaksanaan pengembangan kurikulum dapat dikatakan Cukup Baik. Dalam hal kurikulum, upaya pengembangan dilakukan dengan mensinergikan kurikulum pengajaran pada jurusan yang menjadi subjek internasionalisasi dengan model internasionalisasi yang dikembangkan UB saat ini. Adapun arah pengembangan program internasionalisasi UB disesuaikan oleh kondisi dan kekuatan masing-masing Fakultas, termasuk dalam hal ini terkait kurikulum pengajaran yang dipakai.
Pelaksanaan program internasionalisasi direalisasikan sesuai dengan acuan pemahaman konteks internasionalisasi yang digunakan oleh UB sendiri, yakni membangun proses mengintegrasikan lembaga dan stakeholder kunci - mahasiswa, dosen, dan staf pendukung kependidikan - dalam dunia global. Berdasarkan pemahaman tersebut maka integrasi lembaga perguruan tinggi UB dengan mahasiswa, pengajar, dana tenaga pendukung menjadi fokus arah program internasionalisasi UB. Konsep arah internasionalisasi UB ini dituangkan dalam kisi-kisi model internasionaliasi dan acuan Inisiatif Internasionalisasi.

Kisi-kisi model internasionaliasi dan acuan Inisiatif Internasionalisasi yang digunakan UB ini mensinergikan integrasi antara fokus model internasionalisasi yang diangkat oleh UB selaku lembaga perguruan tinggi dengan mahasiswa, kurikulum dan prodi, serta dosen dan penelitian sebagai stakeholder kunci berjalannya program internasioalisasi universitas. Fokus model internasionalisasi yang diangkat oleh UB sendiri masih terus dikembangkan sesuai kemampuan masing-masing fakultas yang menerapkan program internasionalisasi. Untuk sementara, sejauh ini fokus model internasionalisasi yang diangkat mencakup model inportir, model eksportir, model joint-venture akademik, dan model kemitraan. Keempat model ini sendiri terus dikembangkan sesuai teori lima model dari jangkauan internasional sehingga arah pengembangannya tetap terfokus dan konsisten di masa yang akan datang. Hal ini sesuai dengan teori lima model dari jangkauan internasional, yaitu: (1) model impor; (2) model ekspor; (3) model joint-venture akademik; (4) model kemitraan; dan (5) model pe kampus (Hawawini, 2011). Sementara itu, mahasiswa, kurikulum dan prodi, serta dosen dan penelitian yang sebagai stakeholder kunci dalam program internasioalisasi bertindak sebagai penentu keberhasilan program internasioalisasi yang dilakukan oleh UB. Adanya kisi-kisi model internasionaliasi dan acuan Inisiatif Internasionalisasi yang digunakan UB ini menunjukkan bahwa pelaksanaan proses kebijakan internasionalisasi UB sejauh ini sudah sesuai dengan pemahaman konteks internasionalisasi yang dikembangkan oleh UB.

Selanjutnya pada berdasarkan hasil penilaian proses pengembangan kualitas sumber daya manusia pengajar dapat dikatakan Kurang Baik. Di international office UB saat ini sebenarnya terdapat program Visiting Professor. Program ini menjadi peluang tersendiri yang seharusnya dapat membantu UB dalam mengembangkan SDM pengajar dalam mendukung internasionalisasi. Sebagai target utamanya, program ini dapat membantu pengembangan tenaga pengajar yang memenuhi standar World Class Professor guna menaikkan kualitas 
pengajar dalam program internasionalisasi UB.

Meskipun sudah berjalan dengan baik, tapi pada kenyataannya pelaksanaan program ini masih belum bisa optimal. Pelaksanaan program Visiting Professor untuk mengembangkan standar World Class Professor guna menaikkan kualitas pengajar masih sulit untuk dicapai. Hal ini disebabkan karena sistem penjadwalan program yang terlalu singkat sehingga perencanaan dan pengembangan program masih sangat minim dan pada akhirnya tidak optimal. Selain itu, pelaksanaan program yang terkesan hanya mengejar reputasi internasional menjadikan program ini menjadi kurang optimal. Hal ini menyebabkan pelaksanaan program Visiting Professor untuk mengembangkan standar World Class Professor (WCP) guna menaikkan kualitas pengajar justru disibukkan dengan urusan administrasi seperti pengajuan proposal dan pemenuhan syarat-syarat WCP guna menaiikan reputasi universitas saja. Sementara itu fokus pengembangan SDM pengajar yang seharusnya menjadi kunci pelaksanaan program ini menjadi kurang mendapat perhatian.

Upaya lain terkait pengembangan SDM adalah peberdayaan mahasiswa sebagai tenaga pembantu dalam kegiatan urusan internasional UB. Pembahasan terkait peberdayaan mahasiswa sebagai tenaga pembantu dalam kegiatan urusan internasional ini sendiri masih menjadi masukan dalam Rapat Kerja Evaluasi Program Kerja Tahun 2015 dan Penyusunan Program Kerja 2016 International Office Universitas Brawijaya. Usulan tersebut hingga saat ini masih belum berjalan dengan optimal ditunjukkan dengan minimnya pemberdayaan mahasiswa sebagai relawan pembantu dalam kegiatan urusan internasional UB saat ini. Padahal pemberdayaan mahasiswa ini dapat memberikan dampak positif bagi mahasiswa dan pihak universitas dan membentuk sinergi yang baik antar stakeholder mahasiswa-perguruan tinggi.

Selanjutnya pada berdasarkan hasil penilaian proses upaya perbaikan reputasi dapat dikatakan Sangat Kurang. Selama ini upaya perbaikan reputasi pelaksanaan program internasionalisasi UB dapat dikatakan terlalu dipaksakan tanpa diiringi dengan perbaikan yang menyeluruh. Hal ini dapat dilihat dari masih belum terpenuhinya standart tenaga pengajar, sarana dan prasarana berstandart internasional, dan belum tercapainya target-target yang dicanangkan sebelumnya. Adapun target-target yang dicanangkan dalam program internasionalisasi UB meliputi target kinerja capaian peningkatan kualitas pendidikan, kinerja capaian peningkatan kualitas penelitian dan pengabdian pada masyarakat, kinerja capaian peningkatan kualitas kemahasiswaaan dan alumni, dan kinerja capaian peningkatan kualitas kelembagaan. Hingga saat ini, pencapaian target-target tersebut masih jauh dari standart yang dicanangkan sebelumnya. Padahal target-target inilah yang dari awal dicanangkan menjadi dasar perbaikan kualitas dan reputasi program internasionalisasi UB. Selain itu, peringkat UB dalam hal internasionalisasi juga tergolong stagnan dan bahkan merosot pada tiga tahun terakhir. Hal ini menunjukkan bahwa realisasi rencana perbaikan reputasi UB dalam hal internasionaliasi tidak berjalan sesuai rencana.

Melihat hasil evaluasi input program internasionalisasi yang tergolong baik dan cukup baik, maka pelaksanaan program internasionalisasi yang menunjukkan hasil kurang bagus menunjukkan buruknya realisasi kebijakan publik terkait internasionaliasasi di UB. Inti internasionalisasi pendidikan tinggi mencakup pertukaran fakultas dan mahasiswa, pengajaran bersama dan program penelitian serta internasionalisasi kurikulum. Namun, sangat penting untuk memberikan insentif kepada peserta (staf pengajar, staf dan siswa) dan pengembangan pelaksanaan program itu sendiri yang dapat memfasilitasi keseluruhan proses. Penting juga untuk menetapkan pedoman untuk mengukur tingkat kolaborasi internasional untuk mengidentifikasi kekuatan dan kelemahan proses yang ada. Hal ini yang seharusnya menjadi fokus utama pengembangan proses pelaksanaan program internasionalisasi UB. Sayangnya pada kenyataannya proses pelaksanaan program internasionalisasi UB belum menunjukkan kinerja yang sesuai antara perencanaan (pemberian input) dan pelaksaaan di lapangan.

Terakhir, analisis evaluasi hasil capaian kebijakan internasionalisasi UB. Seperti dijelaskan sebelumnya, hasil pelaksanaan kebijakan internasionalisasi UB hingga saat ini dapat dikategorikan Sangat Kurang. Hal ini dapat dilihat dari hasil analisis pemeringkatan QS Stars sebagai standar internasionalisasi UB 2015-2016. Dalam publikasi World University Ranking (WUR) oleh QS Stars, menunjukkan bahwa rank IO UB pada lima tahun terakhir mengalami penurunan terutama pada tahun 2016/ 2017. Pada saat ini, UB menduduki peringkat fluktuasi di kisaran peringkat 801-1000. Adapun grafik peringkat UB di QS World Ranking 5 tahun terahir dapat dilihat pada Gambar 3.

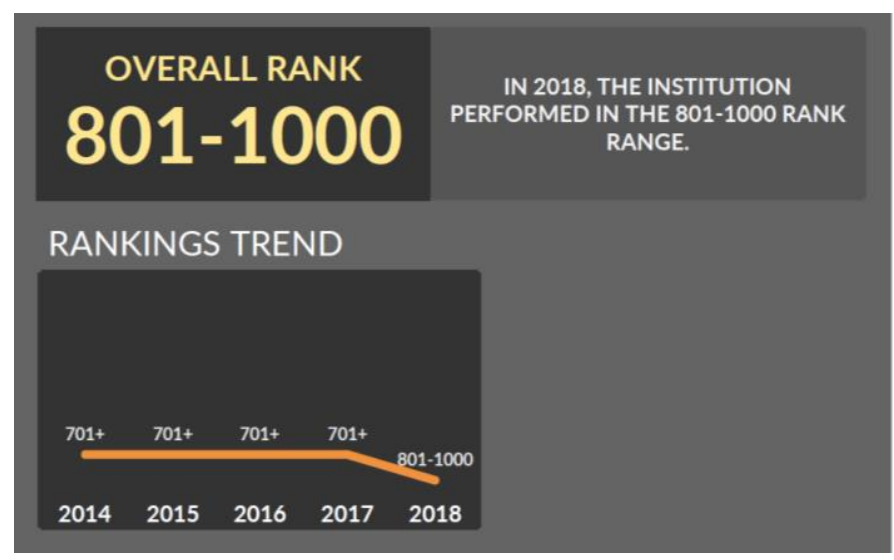


Gambar 3 Peringkat UB di QS World Ranking

Sumber: QS Quacquarelli Symonds Limited, 2018

Sementara pada skala Asia, peringkat internasionalisasi UB juga menunjukkan penurunan peringkat. Dalam publikasi Asia University Ranking (AUR) oleh QS Stars, menunjukkan bahwa rank IO UB pada lima tahun terakhir juga mengalami penurunan terutama pada Tahun 2016-2017. Pada saat ini, UB menduduki peringkat fluktuasi di kisaran peringkat 291300. Adapun grafik peringkat UB di QS Asia Ranking dalam 5 tahun terahir dapat filihat pada Gambar 4.

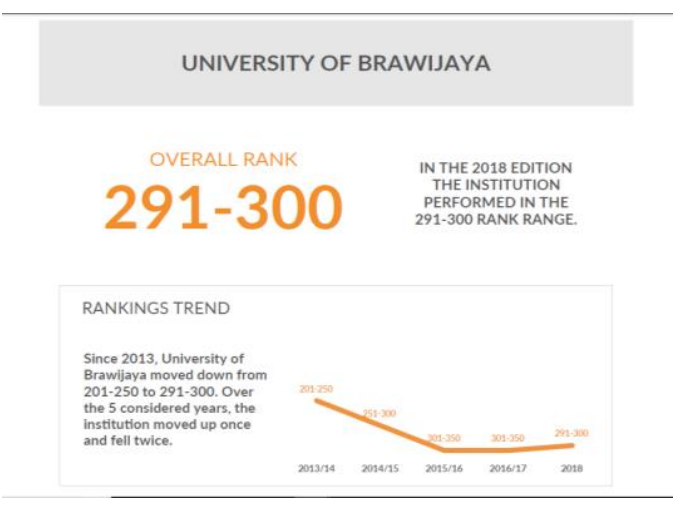

Gambar 4 Peringkat UB di QS Asia

Sumber: QS Quacquarelli Symonds Limited, 2018

Sebagai hasil pelaksanaan kebijakan internasionalisasi UB juga dapat dilihat dari hasil pemeringkatan DIKTI. Berdasarkan hasil pemeringkatan DIKTI, UB mendapatkan penilaian akhir tiga bintang (three stars) dimana nilai maksimum yang tersedia adalah 5 bintang plus. Three Stars menggambarkan tipikal perguruan tinggi yang telah diakui secara nasional dan mulai mendapat pengakuan di bidang internasional. Pada pemeringkatan DIKTI ini, meskipun UB berada pada posisi enam tetapi termasuk pada kluster 1 karena memiliki ciri sebagai berikut: (a) SDM dan infrastruktur kuat berhasil didayagunakan untuk mencapai prestasi nasional yang tinggi; (2) Siap ditingkatkan peringkat internasional; dan (3) Data kegiatan kemahasiswaan belum terekam sepenuhnya. Selain itu, kriteria ini juga didasari oleh karakteristik international office UB yang memiliki program: (a) Penguatan kapasitas untuk membangun reputasi internasional; dan (b) Perekaman data kegiatan kemahasiswaan secara sistematis ke dalam pangkalan data Dikti (Tim Internasionalisasi UB, 2015).

Selain itu, penggolongan international office UB dalam kluster 1 karena kriteria kemahasiswaan Internasional yang sudah memperhatikan penggolongan, leveling, dan faktor kompetisi. Hal ini juga didukung dengan adanya kerjasama Perguruan Tinggi dengan berbagai pihak baik dalam skala nasional maupun internasional. Kerja sama dalam skala Nasional (mengurangi in breeding) ditunjukkan dengan kriteria bahwa dosen UB tidak didominasi oleh yang memiliki riwayat pendidikan lulusan UB. Sementara kerja sama Internasional dilihat dari terbentuknya kerjasama IO UB dengan berbagai universitas luar negeri, yakni Kanazawa university, University of Miyazaki, Tohoku University, Newton Fund, dan Fulbright Specialist Program (Tim Internasionalisasi UB, 2015)

Secara keseluruhan pencapaian hasil prestasi UB dalam hal internasionalisasi belum bisa dikatakan baik terutama pada tahun 2016-2017. Hal ini ditunjukkan dari penurunan peringkat UB sebagai Wolrd Class University baik berdasarkan penilaian QS maupun DIKTI. Dengan demikian, sebagai bentuk evaluasi kebijakan internasionalisasi UB guna membentuk world class university maka perlu dilakukan adanya pembenahan sesuai catatan hasil analisis pemeringkatan QS Stars. Adapun hasil peringkat program internasionalisasi UB dan poin yang perlu dibenahi dari penilaian QS Stars UB meliputi:

a) Rendahnya rasio tenaga pengajar yang mempengaruhi kualitas pengajaran. Rasio mahasiswa: dosen yang belum 10:1 pada kategori Teaching;

b) Jumlah perusahaan internasional yang merekrut alumni UB masih di bawah angka 40 pada kategori employability;

c) Ketersediaan akomodasi mahasiswa yang belum seimbang dengan angka mahasiswa baru yang diterima di UB pada kategori facilities;

d) Proyek kerjasama riset bersama dengan minimal 10 perusahaan luar (bukan institusi UB), dimana hasil risetnya dipublikasikan dalam Scopus pada kategori innovation;

e) Jumlah sitasi per-paper, jumlah paper dari masingmasing fakultas, dan jumlah staf universitas yang diakui internasional yang masih belum memenuhi syarat untuk mendapatkan poin pada kategori research; dan

f) Jumlah kerjasama riset UB dengan universitas lain dalam peringkat 500 QS Stars, jumlah fakultas internasional, jumlah mahasiswa asing, jumlah mahasiswa exchange dan jumlah keragaman asal negara dari mahasiswa asing pada kategori internationalization (Tim Internasionalisasi UB, 2015).

Melihat masih rendahnya pencapaian hasil kebijakan internasionalisasi UB ini menunjukkan masih belum efisiennya pelaksanaan kebijakan tersebut karena belum seimbangnya input, proses, dan hasil yang diperoleh.

\subsection{Kendala Pelaksanaan Kebijakan Internasionalisasi di Universitas Brawijaya}


Kendala dalam pelaksanaan kebijakan internasionalisasi di Universitas Brawijaya disebabkan oleh berbagai faktor. Sejauh ini, hambatan yang dirasakan dalam pengembangan internasionalisasi UB juga dianalisis dari sudut pandang hambatan akademik dan hambatan ekonomi. Berdasarkan hasil rapat kerja Internasional Office UB 2016 diketahui bahwa hambatan akademik untuk internasionalisasi tersebut, antara lain sebagai berikut:

a) Belum tercapainya target standart kualitas tenaga pengajar untuk program internasionalisasi;

b) Belum terpenuhinya kuota pengajar sesuai dengan standart internasional;

c) Belum optimalnya fungsi fasilitas dan laboratorium oleh tenaga pendidik; dan

d) Belum terbentuknya kurikulum yang ideal yang sesuai dengan kurikulum internasional maupun kurikulum universitas partner.

Sementara itu hambatan ekonomi yang dirasakan antara lain biaya internasionalisasi yang tergolong mahal. Inisiatif internasionalisasi berisiko biaya mahal. Inisiatif internasional dapat mahal bukan hanya finansial tetapi juga dari segi waktu yang dialokasikan untuk membuat koneksi dan link ke potensial mitra di masyarakat internasional (Tim Internasionalisasi UB, 2015)

Berdasarkan hasil analisis penelitian, diketahui bahwa berbagai kendala tersebut antara lain: (a) pelaksanaan program yang belum terjadwal dengan baik; (b) keberadaan fasilitas yang belum berperan optimal sesuai fungsinya masing-masing; (c) keberadaan sumber daya manusia pendukung yang masih terkesan dipaksakan; dan (d) orientasi program yang terfokus untuk mengejar prestasi ranking saja dan belum pada peningkatan kinerja. Beberapa kendala ini secara umum memberikan kesulitan tersendiri dalam pengembangan kebijakan internasionalisasi di Universitas Brawijaya. Hal ini terjadi karena kendala yang ada bersifat non primer, artinya kendala yang ada berasal dari faktor pendukung kebijakan yang belum mendukung kebijakan yang ada. Dalam hal ini, segala faktor pendukung kebijakan internasionalisasi di Universitas Brawijaya sudah terpenuhi dan menunjukkan prestasi yang signifikan tapi belum didukung faktor penunjang yang mumpuni sehingga pelaksanaan kebijakannya belum bisa menunjukkan hasil yang seimbang dibandingkan input yang disediakan selama ini.

Dalam hal ini, bagaimana menyamakan persepsi tentang konsep internasionalisasi dalam perspektif dalam pihak internal UB menjadi pertanyaan utama. Pertanyaan yang muncul adalah "Apakah saat ini UB ingin memenuhi standart kompetensi dalam bidang internasionalisasi?" ataukah "Apakah saat ini UB hanya ingin membangun reputasi internasional?". Melihat kondisi saat ini, seharusnya pertanyaan pertama menjadi fokus utama dalam pengembangan international office sebagai pelaksana kebijakan internasionalisasi UB. Namun pada kenyataannya, IO UB saat ini lebih memfokuskan diri dalam mencapai reputasi internasional terlebih dahulu daripada mengembangkan kompetensi dan membangun fondasi untuk mencapai reputasi dimasa yang akan datang. Hal ini menjadi salah satu fokus dalam workshop reputasi internasional UB 2016. Berikut salah satu masukan dalam workshop tersebut yang menjadi sorotan utama.

Salah satu peserta Workshop Reputasi Internasional UB 2016 mengatakan: "Melihat kondisi riil UB saat ini bukan memecahkan masalah global atau juga membangun reputasi. Namun UB saat ini sedang membangun pondasi dulu untuk terwujudnya reputasi UB. Kebijakan yang baik seharusnya adalah kebijakan yang memiliki unsur baseline dan langkah-langkah ke depan yang akan dilaksanakan". Argumen tersebut memberikan kritik dalam pelaksanaan kebijakan internasional UB saat ini yang dirasa hanya terfokus pada pencapaian reputasi dibandingkan peningkatan kompetensi saat ini. Pada kenyataannya pencapaian prestasi IO UB saat ini sulit untuk dikembangkan lebih lanjut karena faktor-faktor pendukung yang kurang kompeten dan belum optimal. Pelaksanaan kebijakan internasionalisasi saat ini lebih terkesan pada bagaimana memenuhi persyaratan untuk menjadi universitas internasional (WCU) dibandingkan dengan bagaimana membangun kompetensi yang mumpuni sebagai universitas internasional (WCU) itu sendiri. Hal ini menjelaskan kenapa komponen-komponen utama dalam mendukung program internasionalisasi UB dapat digolongkan mumpuni sementara pemanfaatannya kurang optimal dan belum ditunjang oleh komponen pendukung yang mumpuni. Dalam jangka panjang, kondisi ini akan menjadi kendala utama yang dapat menghambat pengembangan program internasionalisasi UB itu sendiri.

\section{Kesimpulan}

Kebijakan internasionalisasi yang dibuat oleh UB bisa dicerminkan dari visi dan misi UB, Rencana Strategis, dan Draft Kebijakan Rektor Internasionalisasi UB, dari semua dokumen tersebut belum ada strategi yang jelas dalam mencapai tujuan UB yaitu menjadi World Class Enterprenurial University. Kebijakan tersebut lebih menekankan pada peningkatan reputasi internasional atau ranking, dan belum ada SK Rektor khusus yang membahas program internasionalisasi UB. Lebih lanjut, tidak adanya Policy Guidelines atau panduan dalam meraih tujuan UB tersebut membuat peneliti tidak bisa mengukur kesesuaian antara Policy 
Guideline dan informasi dari informan, observasi maupun data yang didapatkan dari penelitian.

Sesuai tahapan evaluasi yang dipakai, evaluasi yang digunakan pada penelitian ini adalah adalah evaluasi input, evaluasi proses dan evaluasi output. Berikut dipaparkan rincian tiap tahap evaluasi yang dilakukan :

Dari segi input, bisa dikatakan baik namun masih bisa dioptimalkan lagi. Evaluasi proses kebijakan internasionalisasi UB dapat dikatakan cukup baik hanya saja fokus pelaksanaan masih terbatas pada pemenuhan standar program internasionalisasi, dan belum difokuskan pada pengembangan kualitas dan kuantitas program yang dijalankan. Hasil pelaksanaan kebijakan internasionalisasi UB hingga saat ini dapat dikategorikan kurang bagus. Hal ini terihat dari terus menurunnya peringkat UB dalam World Rank QS maupun penilaian DIKTI.

Berdasarkan hasil analisis penelitian, diketahui bahwa berbagai kendala tersebut antara lain: (a) pelaksanaan program belum yang terjadwal dengan baik; (b) keberadaan fasilitas yang belum berperan optimal sesuai fungsinya masing-masing; (c) keberadaan sumber daya manusia pendukung yang masih terkesan dipaksakan; dan (d) orientasi program yang terfokus untuk mengejar prestasi ranking saja dan belum pada peningkatan kinerja.

\section{Daftar Pustaka}

Creswell. John W. (2012). Research Design Pendekatan Kualitatif, Kuantitatif dan Mixed, Edisi Ketiga, Penerjemah Ahmad Fawaid. Yogyakarta: Pustaka Pelajar.

Dunn, William N. (2000). Pengantar Analisis Kebijakan Publik, Penterjemah: Samudra Wibowo, dkk. Yogyakarta: Gajah Mada University Press.

Dye, Thomas R. (1992). Understanding Public Policy. Englewood Cliffs, NJ: Prentice-Hall

Ellingboe, B. J. (1998). Divisional Strategies to Internationalize a Campus Portrait: Results, Resistance, and Recommendations From a Case Study at U.S. University. Phoenix, AZ: The American Council on Education and The Oryx Press.

Harari, M. (1977). Trends and Issues in Globalizing Higher Education. Washington, D.C: American Association of State Colleges and Universities.

Hawawini, G. 2011. Faculty and Research Working Paper: The Internationalization of Higher Education Institutions: A Critical Review and A Radical Proposal. Tersedia pada https://sites.insead.edu/facultyresearch/research/do c.cfmid=48726 [Diakses pada 15 Desember 2017].
ICEF (International College of Economy and Finance). (2015). The Growth of International Student Mobility 1990-2014. Tersedia pada http://monitor.icef.com/2015/11/the-state-ofinternational-student-mobility-in-2015/studentmobility-growth/ [Diakses pada 8 Desember 2017].

Nawawi, Ismail. (2009). Public Policy Analisis, Strategi Advokasi Teori dan Praktek. Surabaya: PMN.

Patton, Carl. V., \& Sawicki, David S. (1993). Basic Methods of Policy Analysis, Second Edition. Prentice Hall: Englwood Cliffs, NJ.

QS Quacquarelli Symonds Limited. (2018). University of Brawijaya World Rankings and Asian Rankings. Diakses pada https://www.topuniversities.com/universities/univ ersity-brawijaya [Diakses pada 22 Desember 2017].

Thompson, Nancy J. \& McClintock, Helen O. (2000). Demonstrating Your Program's Worth A primer on Evaluation for Programs to Prevent Unintentional Injury. Atlanta, Georgia: National Center for Injury Prevention and Control.

Tim Internasionalisasi UB. (2015). Draft Kebijakan Rektor Internasionalisasi UB 2015-2019. Malang: Universitas Brawijaya (UB).

UB (Universitas Brawijaya). (2011). Rencana Strategis Universitas Brawijaya 2011-2015. Malang: Universitas Brawijaya.

UB (Universitas Brawijaya). (2015). Rencana Strategis Universitas Brawijaya 2015-2019. Malang: Universitas Brawijaya.

Wahab, Solichin Abdul. (2008). Pengantar Analisis Kebijakan Publik. Malang: UMM Press.

Winarno, Budi. (2012). Kebijakan Publik (Teori, Proses, dan Studi Kasus). Buku Seru: Yogyakarta

Yunlai, W., \& D. Zhehua. (2008). Progressive Internationalization: Nanjing University's Theory and Practice. Tersedia pada http://www.wun.ac.uk/theglobaluniversity/docume nts/papers/14Nov/WangNanjing.pdf [Diakses pada 10 Desember 2017]. 